\title{
Pemanfaatan Asap Cair Food Grade yang Dimurnikan dengan Arang Aktif sebagai Pengawet Ikan Nila
}

\section{The Utilization of Food Grade Liquid Smoke Purified by Activated Charcoal as Tilapia Fish Preservative}

\author{
Siti Salamah $^{1 a^{*}}$, Siti Jamilatun ${ }^{2 a}$ \\ ${ }^{a}$ Program Studi Teknik Kimia Universitas Ahmad Dahlan, \\ Jl. Prof. Soepomo SH, Yogyakarta 55164, Indonesia
}

\section{Artikel histori :}

Diterima 8 September 2017 Diterima dalam revisi 11 Desember 2017 Diterima 21 Desember 2017 Online 30 Desember 2017

\begin{abstract}
ABSTRAK: Bau asap serta warna kuning pada asap cair dapat dikurangi dengan penyerapan menggunakan arang aktif. Arang aktif yang telah diaktivasi dapat mengurangi bau dan warna asap cair sebesar 20\%. Asap cair tersebut mengalami peningkatan kemampuan pengawetan dengan meningkatnya kadar asam asetat hampir 3 kali lipat. Dalam penelitian ini dilakukan pemanfaatan asap cair food grade yang dimurnikan dengan arang aktif untuk pengawetan bahan makanan yaitu ikan Nila. Percobaan dilakukan dengan mencampurkan arang aktif yang telah diaktivasi dengan asap cair, kemudian diaduk dan disaring. Ikan Nila direndam dalam asap cair yang telah dimurnikan dengan variasi waktu penyimpanan yaitu 3,6,9,12 dan 15 jam. Perlakuan diulang dengan variasi kadar asap cair yaitu 5\%,7,5\%,10\%, 12,5\%, 15\% dan $17,5 \%$. Ikan Nila yang telah diawetkan dianalisis kadar protein, jumlah total bakteri, uji fisik dan $\mathrm{pH}$. Dari penelitian ini diperoleh konsentrasi optimum asap cair sebagai pengawet adalah 15\%.Kadar protein pada ikan Nila yang direndam menggunakan asap cair selama masa simpan 15 jam adalah $15,15 \%$. Jumlah total bakteri dalam ikan Nila adalah antara $4,5 \times 10^{6}-5,4 \times 10^{8}$ CFU/ g. Penggunaan asap cair $10 \%$ pada ikan Nila mampu mempertahankan kondisi fisik ikan selama waktu simpan 3 jam dengan pH5. Semakin banyak jumlah total bakteri maka kadar proteinnya semakin rendah.
\end{abstract}

Kata Kunci: asap cair food grade; arang aktif; pemurnian

\begin{abstract}
The smell of smoke and yellow color in liquid smoke can be reduced by using activated charcoal. Activated charcoal can reduce the odor and color of liquid smoke by $20 \%$. The ability of liquid smoke to preserve increaseswith the increase of acetic acid concentration almost 3 times. The utilization of purified food grade liquid smoke for Nila fish preservation was done. The experiment was carried out by mixing activated charcoal with liquid smoke, then stirred and filtered. Tilapia fish soaked in liquid smoke with variations of storage time are $3,6,9,12$ and 15 hours. The treatments were repeated with variations in liquid smoke concentration of $5 \%, 7.5 \%, 10 \%, 12.5 \%, 15 \%$ and $17.5 \%$. The preserved fish were analyzed to know protein content, total bacteria, physical test and $\mathrm{pH}$. From this research, optimum liquid smoke concentration as preservative was $15 \%$. Protein content in fish soaked in liquid smoke for 15 hours was $15.15 \%$. The total amount of bacteria in fishwas $4.5 \times 10^{6}-5.4 \times 10^{8} \mathrm{CFU} / \mathrm{g}$. The use of $10 \%$ liquid smoke in fish was able to maintain the physical condition of fish for 3 hours with $\mathrm{pH}$ 5. The more the total number of bacteria the lower the protein content.

Keywords: food grade liquid smoke; activated charcoal; purification.
\end{abstract}

\section{Pendahuluan}

Saat ini perkembangan teknologi terkait pengawetan makanan semakin meningkat. Penelitian-penelitian tentang pengawetan makanan terus dilakukan untuk mendapatkan pengawet makanan yang aman bagi tubuh. Salah satu inovasi terbaru yaitu penggunaan asap cair sebagai bahan pengawet yang aman untuk dikonsumsi manusia.
Asap cair (liquid smoke) merupakan suatu hasil distilasi atau pengembunan dari uap hasil pembakaran tidak langsung maupun langsung dari bahan-bahan yang mengandung karbon (Yunus, 2011), serta senyawasenyawa lain sepertihemiselulosa, sellulosa, dan lignin (Darmadji, 2009). Secara umum, kayu yang digunakan untuk menghasilkan asap cair kira-kira terdiri dari $25 \%$ hemiselulosa, 50\% selulosa, dan 25\% lignin (Lingbeck, et al., 2014). Asap cair mempunyai potensi yang cukup baik sebagai antioksidan, pengawet alami maupun sebagai

*Corresponding Author

Email: sitisalamah@che.uad.ac.id 
antimikroba pada produk olahan seperti bakso ikan (Yunus, 2011).

Komposisi dari asap cair dipengaruhi oleh kandungan selulosa, hemiselulosa dan lignin. Komponen tersebut jika mengalami pirolisis akan menghasilkan asam, fenol, karbonil dan senyawa-senyawa lain yang terdapat dalam asap cair. Jika lignin dipirolisis akan menghasilkan senyawa seperti methyl ester, piragol, tar dan lain-lain, sedangkan selulosa jika mengalami pirolisis akan menghasilkan asam asetat, furan dan fenol.Senyawa yang berhasil dideteksi dalam asap cair dikelompokkan menjadi beberapa golongan yaitu fenol, karbonil, keton dan aldehid, furan, polisiklik, dan polisiklik aromatik hidrokarbon (PAH) (Atmaja, 2009). Senyawa utama yang terdapat dalam asap cairdiantaranya adalah fenol, karbonil dan senyawa asam (Jamilatun dan Salamah, 2015). Pirolisis komponen hemiselulosa dan selulosa terjadi pada suhu $180-350{ }^{\circ} \mathrm{C}$, sedangkan pirolisis komponen lignin terjadi pada suhu $300-500{ }^{\circ} \mathrm{C}$ (Lingbeck, et al., 2014).

Proses pembuatan asap cair melalui beberapa tahapan yaitu pirolisis, kondensasi dan re-distilasi. Asap cair yang dikondensasikan masih memiliki kandungantardan berwarna keruh, sehingga perlu dilakukan distilasi berulang-ulang (Yunus, 2011; Jamilatun dan Salamah, 2015). Arang aktif merupakan salah satu adsorben yang memiliki potensi untuk menghilangkan bau menyengat dan menjernihkan warna pada asap cair. Berdasarkan penelitian sebelumnya asap cair food grade sebelum dan sesudah pemurnian mengalami penyerapan. Hasil analisis GC-MS arang aktif yang diaktivasi dapat menurunkan kadar asam karbonil $100 \%$ dan fenol $20 \%$ sebagai komponen yang mempengaruhi flavor dan warna.

Prospek implementasi asap cair sangat luas, mencakup industri makanan sebagai pengawet, industri kesehatan, pupuk tanaman, bio-insektisida, pestisida, desinfektan, herbisida, dan lain sebagainya yang memiliki berbagai keunggulan bila dibandingkan dengan penggunaan bahan kimia sintetik.Dengan adanya inovasi baru berupa asap cair ini diharapkan dapat menggurangi penggunaan zat aditif atau bahan-bahan pengawet yang tidak aman bagi kesehatan misalnya penggunaan boraks, formalin, dan sebagainya.

Asap cair dapat memperpanjang masa simpan produk dengan mencegah kerusakan akibat aktivitas bakteri pembusuk dan patogen. Senyawa yang mendukung sifat antibakteri dalam distilat asap cair adalah senyawa fenol dan asam. Senyawa fenol dapat menghambat pertumbuhan populasi bakteri dengan memperpanjang fase lag secara proposional di dalam produk,sedangkan kecepatan pertumbuhan dalam fase eksponensial tetap tidak berubah, kecuali konsentrasi fenol yang tinggi. Fraksi fenol yang mampu menghambat pertumbuhan bakteri adalah fenol dengan titik didih rendah.Asam lebih kuat menghambat pertumbuhan bakteri pada senyawa fenol, namun apabila keduanya digabungkan akan menghasilkan kemampuan penghambat yang lebih besar daripada masing-masing senyawa. Komponen antioksidatif asap adalah senyawa fenol yang bertindak sebagai donor hidrogen dan biasanya afektif dalam jumlah sangat kecil untuk menghambat reaksi oksidasi. Sifatantioksidatif asap cair disebabkan oleh fenol titik didih tinggi terutama 2,6-etil fenol. Fenol bertitik didih rendah menunjukkan sifat antioksidatif yang lemah. Turunan senyawa fenol dalam asap cair yang bersifat antioksidatif adalah pirokatekol, hidroquinon, guaiakol, eugenol, iso-eugenol, vanilin, salisilaldehid, asam2-hidroksibenzoat dan asam 4-hidroksibenzoat (Darmadji, 2009).

Daging dan ikan selain merupakan salah satu sumber protein hewani, juga merupakan media yang baik untuk pertumbuhan mikroorganisme terutama bakteri, sehingga penyediaan daging dan ikan yang cukup jumlahnya dan memenuhi syarat kesehatan sangat dipengaruhi oleh penanganan terhadap bakteri pada daging, agar tidak terjadi kerusakan pada daging atau menimbulkan penyakit pada manusia. Beberapa bakteri yang umumnya dapat menimbulkan kerusakan pada daging dan ikan, antara lain dari genus Pseudomonas, Achromobacter, Streptococcus, Leuconostoc,Bacillus, dan Micrococcus(Purwani dan Hapsari, 2011).

Ikan Nila (Oreochromis sp.) merupakan jenis ikan budidaya air tawar yang banyak disukai oleh masyarakat. Ikan Nila adalah potensi ekspor komoditas di Indonesia. Total produksi ikan Nila nasional per tahun 2015 adalah mencapai 912.613 ton/ tahun (Ariestya, et al., 2016). Hal ini dikarenkan ikan Nila merah memiliki beberapa keunggulan dibandingkan dengan jenis ikan air tawar lainnya, karena selain mudah dibudidayakan, ikan Nila juga memiliki banyak gizi, daging yang tebal dan duri yang relatif sedikit. Ikan Nila memiliki kandungan gizi yang lebih baik dibandingkan dengan ikan tawar lainnya. Kandungan protein ikan Nila sebesar 43,76\%, lemak $7,01 \%$, kadar abu 6,80\%, dan air 2,28\% per 100 gram berat ikan (Purwani dan Hapsari, 2011) .

Ikan merupakan salah satu bahan pangan yang mengandung banyak gizi, akan tetapi cepat mengalami proses pembusukan. Hal ini disebabkan karena kandungan protein yang tinggi dan kondisi lingkungan yang sangat mendukung untuk pertumbuhan mikroba. Oleh sebab itu, sangat penting bagi masyarakat yang akan mengkonsumsi ikan untuk lebih berhati-hati dan memperhatikan kesegaran ikan. Adapun ciri-ciri ikan yang mulai mengalami pembusukan dapat dilihat dari kenampakan luar, kelenturan daging, keadaan mata, keadaan insang, sisik dan $\mathrm{pH}$. Ikan yang sudah tidak segar atau mengalami pembusukan memiliki $\mathrm{pH}$ yang tinggi (basa). Hal ini disebabkan karena adanya senyawa-senyawa yang bersifat basa, misalnya: amoniak, trimetilamin, dan senyawa volatile lainnya.

Kemerosotan kualitas ikan dapat dapat dicegah dengan pengawet alami yang mengandung komponen bioaktif untuk mencegah aktivitas bakteri (Ariestya, et al., 2016). Asap cair memiliki senyawa bioaktif seperti fenol, karbonil, dan asam organik yang berfungsi sebagai antibakteri yang dapat menjaga kualitas ikan (Saloko, et al., 2014). 
Beberapa penelitian yang telah dilakukan menunjukkan penambahan asap cair dapat memperpanjang waktu simpan suatu produk. Bahkan ada beberapa produk asap cair yang sudah diperdagangkan secara luas. Namun, sebagian masyarakat masih ragu untuk menggunakan asap cair tersebut.Peningkatan kualitas asap cair dapat dilakukan dengan cara penjernihan menggunakan arang aktif (Ayudiarti dan Sari, 2010).Arang aktif merupakan salah satu adsorben yang memiliki potensi untuk menghilangkan bau menyengat dan menjernihkan warna pada asap cair. Berdasarkan penelitian sebelumnya asap cair food grade sebelum dan sesudah pemurnian mengalami penyerapan oleh arang aktif. Hasil analisis GC-MS arang aktif yang diaktivasi dapat menurunkan kadar asam karbonil 100\% dan fenol 20\% sebagai komponen yang mempengaruhi flavour dan warna. Dalam penelitian ini, akan dilakukan penelitian untuk memanfaatkan asap cair (food grade) komersil yang sudah dimurnikan menggunakan arang aktif, untuk aplikasi pada ikan, misalnya ikan Nila.

\section{Metode Penelitian}

\subsection{Alat}

Alat-alat yang digunakan dalam penelitian ini adalahalatalat gelas, pinset, penyaring, muffel, dan plastik tempat sampel.

\subsection{Bahan}

Bahan-bahan yang digunakan dalam penelitian ini adalah arang aktif dari PT. Brataco, asap cair food grade, aquadest, $\mathrm{H}_{2} \mathrm{SO}_{4}$ (Teknis) $2 \mathrm{~N}$, dan ikan Nila.

\subsection{Cara Kerja}

Arang aktif yang telah diaktivasi dengan $\mathrm{H}_{2} \mathrm{SO}_{4} 2 \mathrm{~N}$ dicampurkan dengan asap cair (food grade), kemudian dilakukan pengadukan dan penyaringan. Hasil asap cair yang sudah dimurnikan (jernih dan tidak berbau asap menyengat, karena kandungan asam karboksilat dan fenol mengalami penurunan), digunakan untuk merendam ikan Nila yang telah dibersihkan selama 20 menit, dengan variasi kadar asap cair 5\%, 7,5\%, 10\%, 12,5\%, 15\%, $17,5 \%$.

Ikan Nila kemudian ditiriskan dan disimpan dengan variasi waktu penyimpanan 3 jam, 6 jam, 9 jam, 12 jam, dan 15 jam. Ikan Nila yang telah diawetkan dengan asap cair (food grade), baik yang telah dimurnikan maupun tidak dimurnikan, dianalisis kadar proteinnya menggunakan metode Kjedahl, jumlah total bakterinya menggunakan metode Total Plate Count (TPC), uji fisik dan kadar $\mathrm{pH}$.

\section{Hasil dan Pembahasan}

\subsection{Hasil Pemurnian Asap Cair Menggunakan Arang Aktif}

Hasil pemurnian asap cair menggunakan arang aktif dapat dilihat pada Tabel 1 .
Berdasarkan pada Tabel 1, dapat dilihat bahwa, arang aktif memberikan pengaruh pada pengurangan bau yang sangat menyengat dan menurunkan $\mathrm{pH}$, sedangkan kekeruhan semakin bertambah karena cukup banyak ada sebagian kotoran yang larut dalam asap cair.

Tabel 1. Hasil pemurnian asap cair menggunakan arang aktif

\begin{tabular}{ccc}
\hline Parameter & $\begin{array}{c}\text { Sebelum } \\
\text { Pemurnian }\end{array}$ & $\begin{array}{c}\text { Setelah } \\
\text { Pemurnian }\end{array}$ \\
\hline Warna & Keruh/ & Tambah keruh \\
& kecoklatan & \\
Bau & Bau asap & Bau asap \\
& menyengat & berkurang \\
$\mathrm{pH}$ & $4-4,5$ & 2,6 \\
\hline
\end{tabular}

Penggunaan arang aktif idealnya digunakan pada asap cair yang sudah dijernihkan dengan distilasi, bukan asap cair hasil langsung pirolisis karena keasamannya yang sangat tinggi. Menurut Darmadji (2009), penggunaan arang aktif pada asap cair hasil distilasi untuk menurunkan benzopiron dan bau menyengat. Dari hasil penelitian Jamilatun dan Salamah (2015) sebelumnya, asap cair yang murni mengendung asam asetat 2,65\%, phenol 54,58 \%, metoksi $11,72 \%$, benzena $12,86 \%$. Setelah perendaman menggunakan arang aktif beberapa senyawa mengalami penurunan.

\subsection{Hasil Analisis Protein dan Total Plate CountPada Sampel Ikan Nila yang Direndam Menggunakan Asap Cair}

Hasil analisis kadar protein dan jumlah total bakteri pada sampel ikan Nila yang direndam menggunakan asap cair dengan variasi konsentrasi dapat dilihat pada Tabel 2 berikut ini.

Tabel 2. Hasil analisis kadar protein dan jumlah total bakteri sampel ikan Nila yang direndam menggunakan asap cair selama masa simpan 3 jam

\begin{tabular}{ccc}
\hline $\begin{array}{c}\text { Konsentrasi } \\
\text { Asap Cair (\%) }\end{array}$ & $\begin{array}{c}\text { Kadar } \\
\text { Protein } \\
(\%)\end{array}$ & $\begin{array}{c}\text { TPC } \\
(\text { CFU/ g) }\end{array}$ \\
\hline 5 & 15,33 & $5,1 \times 10^{6}$ \\
7,5 & 15,95 & $1,8 \times 10^{7}$ \\
10 & 16,29 & $7,8 \times 10^{6}$ \\
12,5 & 15,98 & $8,0 \times 10^{6}$ \\
15 & 17,02 & $7,2 \times 10^{7}$ \\
17,5 & 17,30 & $1,72 \times 10^{8}$ \\
\hline
\end{tabular}

Berdasarkan hasil analisis kadar protein sampel ikan Nila yang terdapat pada Tabel 2, dapat diketahui bahwa kadar protein mengalami kenaikan dan penurunan. Pada kadar $10 \%$, kadar protein naik sebanyak $0,34 \%$ dari yang sebelumnya. Hal ini menunjukkan bahwa asap cair berperan aktif sebagai antimikroba yang dapat menghambat pertumbuhan bakteri. Namun peran aktif asap cair sebagai penghambat pertumbuhan bakteri masih sangat rendah. 
Pada perendaman sampel ikan Nila dengan kadar asap cair $12,5 \%$, kadar protein mengalami penurunan sebanyak $0,31 \%$. Pada konsentrasi asap cair $15 \%$ dan $17,5 \%$, kadar protein mengalami peningkatan kembali. Hal ini terjadi karena pada kadar asap cair 12,5\%, kandungan senyawa fenol sebagai antibakteri menurun, ditandai dengan jumlah bakteri pada kadar asap cair tersebut merupakan yang paling tinggi yaitu $8 \times 10^{6} \mathrm{CFU} / \mathrm{g}$. Dibandingkan dengan penelitian sebelumnya (Jamilatun, Salamah 2016), kadar protein ikan nila yang direndam dengan asap cair tanpa pemrnian kadar proteinnya lebih rendah yang menyebabkan jumlah bakteri semakin banyak. Pada kadar $17,5 \%$ sebelum pemurnian kadar protein $16,5 \%$ dan dengan pemurnian $17,30 \%$.

\subsection{Hasil Analisis Protein dan Total Plate CountPada} Sampel Ikan Nila dengan Variasi Waktu Penyimpanan

Pada tahap ini sampel ikan Nila direndam menggunakan asap cair food grade yang dimurnikan dengan konsentrasi $10 \%$, kemudian sampel disimpan dengan variasi waktu penyimpanan selama 15 jam. Sampel disimpan dengan variasi waktu selama 15 jam dengan tujuan untuk mengetahui pengaruh asap cair terhadap masa simpan dan kadar proteinnya.

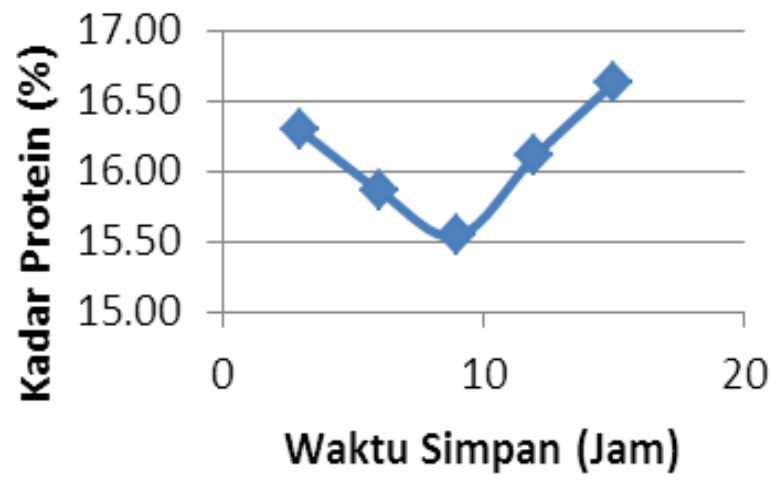

Gambar 1. Grafik Hubungan Waktu Simpan dengan Kadar Protein Ikan Nila yang Direndam Menggunakan Asap Cair $10 \%$.

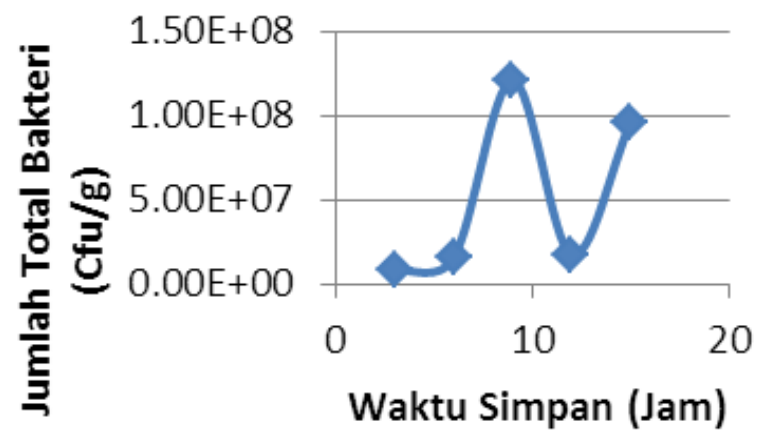

Gambar 2. Grafik Hubungan Waktu Simpan dengan Jumlah Total Bakteri Ikan Nila yang Direndam Menggunakan Asap Cair10\%
Hasil analisis kadar protein dan TPC sampel ikan Nila yang direndam menggunakan asap cair 10\%, dengan variasi waktu penyimpanan selama 15 jam dapat di lihat pada Gambar 1 dan 2.

Berdasarkan hasil analisis kadar protein dan jumlah total bakteri pada gambar 1 dan 2, diketahui bahwa jumlah total bakteri mempengaruhi kadar protein yang ada dalam sampel. Pada saat jumlah total bakteri sedikit, maka kadar protein pada sampel ikan Nila tinggi.

Perendaman sampel menggunakan asap cair $10 \%$ yang disimpan selama 3 jam, memiliki jumlah total bakteri sebanyak 7,8 x $10^{6} \mathrm{CFU} / \mathrm{g}$ dan kadar protein sebanyak $16,285 \%$. Kadar protein sampel ikan Nila relatif tinggi, dikarenakan bakteri yang mengubah asam amino menjadi amonia relatif sedikit.

3.4 Hasil Uji Fisik Pada Sampel Ikan Nila yang Direndam Menggunakan Asap Cair Food Grade yang Dimurnikan dengan Variasi Konsentrasi

Hasil uji fisik pada sampel ikan Nila dengan asap cair yang dimurnikan kembali terdapat pada Tabel 3 .

Penggunaan asap cair food grade ini bertujuan untuk mengetahui pengaruh pemurnian terhadap daya simpan dan kualitas sampel ikan. Tabel 3 merupakan hasil uji fisik sampel ikan Nila yang direndam menggunakan asap cair dengan variasi konsentrasi. Berdasarkan hasil uji fisik terhadap sampel ikan Nila pada masa simpan 3 jam, dapat dilihat bahwa perendaman sampel menggunakan asap dengan kadar 5-7,5\% belum mampu menghambat pertumbuhan bakteri.

Pada masa simpan selama 3 jam, terdapat penurunan kualitas yaitu terjadinya perubahan warna khas yang semula terlihat jelas menjadi pudar, sedangkan perendaman sampel ikan menggunakan asap cair,dengan kadar 10$17,5 \%$ dapat menghambat pertumbuhan bakteri. Hal ini dapat dilihat dari hasil uji fisik di beberapa indikator yaitu pada mata, bau, dan warna khas. Oleh karena itu, batas minimal penggunaan asap cair yaitu pada konsentrasi $10 \%$.

3.5 Hasil Uji Fisik Pada Sampel Ikan Nila yang Direndam Menggunakan Asap Cair Food Grade yang Dimurnikan dengan Variasi Waktu Penyimpanan

Asap cair yang digunakan penelitian ini adalah asap cair food grade yang dimurnikan menggunakan arang aktif. Penggunaan asap cair dalam pengawetan sampel ikan Nila bertujuan untuk memperpanjang masa simpan ikan Nila.

Hasil uji fisik sampel ikan Nila yang direndam menggunakan asap cair dengan konsentrasi $10 \%$ terdapat pada Tabel 4 .

Berdasarkan hasil uji fisik sampel ikan Nila pada Tabel 4, perendaman sampel ikan Nila menggunakan asap cair dengan kadar $10 \%$ dapat menghambat pertumbuhan bakteri selama 6 jam penyimpanan. Sampel ikan Nila yang direndam menggunakan asap cair mampu bertahan 3 jam lebih lama. Perbedaan waktu simpan ini dapat dipengaruhi oleh senyawa-senyawa yang terkandung dalam asap cair. 
Tabel 3. Hasil uji fisik pada sampel ikan yang direndam menggunakan asap cair dengan variasi konsentrasi pada masa simpan selama 3 jam

\begin{tabular}{|c|c|c|c|c|c|c|c|}
\hline \multirow{2}{*}{$\begin{array}{l}\text { Uji Fisik } \\
\text { (Jam) }\end{array}$} & \multirow{2}{*}{ Indikator } & \multicolumn{6}{|c|}{ Konsentrasi } \\
\hline & & $5 \%$ & $7,5 \%$ & $10 \%$ & $12,5 \%$ & $15 \%$ & $17,5 \%$ \\
\hline \multirow[t]{8}{*}{ Ke-0 } & Mata & $\begin{array}{l}\text { Jernih dan } \\
\text { cembung }\end{array}$ & $\begin{array}{l}\text { Jernih dan } \\
\text { cembung }\end{array}$ & $\begin{array}{l}\text { Jernih dan } \\
\text { cembung }\end{array}$ & $\begin{array}{l}\text { Jernih dan } \\
\text { cembung }\end{array}$ & $\begin{array}{l}\text { Jernih dan } \\
\text { cembung }\end{array}$ & $\begin{array}{l}\text { Jernih dan } \\
\text { cembung }\end{array}$ \\
\hline & Sisik & Menempel & Menempel & Menempel & Menempel & Menempel & Menempel \\
\hline & Daging & Elastis & Elastis & Elastis & Elastis & Elastis & Elastis \\
\hline & Insang & $\begin{array}{l}\text { Coklat } \\
\text { Kemerahan }\end{array}$ & Coklat muda & Coklat muda & Coklat muda & Coklat muda & $\begin{array}{l}\text { Coklat } \\
\text { muda }\end{array}$ \\
\hline & Bau & Asap cair & Asap cair & Asap cair & Asap cair & Asap cair & Asap cair \\
\hline & Kulit & Kencang & Kencang & Kencang & Kencang & Kencang & Kencang \\
\hline & Lendir & Tidak ada & Tidak ada & Tidak ada & Tidak ada & Tidak ada & Tidak ada \\
\hline & Warna & $\begin{array}{l}\text { Warna khas } \\
\text { masih ada }\end{array}$ & $\begin{array}{l}\text { Warna khas } \\
\text { masih ada }\end{array}$ & $\begin{array}{l}\text { Warna khas } \\
\text { masih ada }\end{array}$ & $\begin{array}{l}\text { Warna khas } \\
\text { masih ada }\end{array}$ & $\begin{array}{l}\text { Warna khas } \\
\text { masih ada }\end{array}$ & $\begin{array}{l}\text { Warna khas } \\
\text { masih ada }\end{array}$ \\
\hline \multirow[t]{8}{*}{ Ke-3 } & Mata & $\begin{array}{l}\text { Jernih dan } \\
\text { cekung }\end{array}$ & $\begin{array}{l}\text { Jernih dan } \\
\text { cekung }\end{array}$ & $\begin{array}{l}\text { Jernih dan } \\
\text { cembung }\end{array}$ & $\begin{array}{l}\text { Jernih dan } \\
\text { cembung }\end{array}$ & $\begin{array}{l}\text { Jernih dan } \\
\text { cekung }\end{array}$ & $\begin{array}{l}\text { Jernih dan } \\
\text { cembung }\end{array}$ \\
\hline & Sisik & Lepas & Menempel & Menempel & Menempel & Menempel & Menempel \\
\hline & Daging & Tidak elastis & Elastis & Elastis & Elastis & Elastis & Elastis \\
\hline & Insang & Coklat tua & Coklat muda & Coklat muda & Coklat tua & Coklat tua & Coklat tua \\
\hline & Bau & Amis & $\begin{array}{l}\text { Amis dan } \\
\text { bau asap }\end{array}$ & Asapcair & Asap cair & Asap cair & Asap cair \\
\hline & Kulit & Keriput & $\begin{array}{l}\text { Cair } \\
\text { Kencang }\end{array}$ & Kencang & Kencang & Kencang & Kencang \\
\hline & Lendir & Tidak ada & Tidak ada & Tidak ada & Tidak ada & Tidak ada & Tidak ada \\
\hline & Warna & $\begin{array}{l}\text { Warna khas } \\
\text { mulai pudar }\end{array}$ & $\begin{array}{l}\text { Warna khas } \\
\text { mulai pudar }\end{array}$ & $\begin{array}{l}\text { Warna khas } \\
\text { masih ada }\end{array}$ & $\begin{array}{l}\text { Warna khas } \\
\text { masih ada }\end{array}$ & $\begin{array}{l}\text { Warna khas } \\
\text { mulai pudar }\end{array}$ & $\begin{array}{l}\text { Warna khas } \\
\text { masih ada }\end{array}$ \\
\hline
\end{tabular}

Berdasarkan hasil penelitian sebelumnya,pemurnian asap cair menggunakan arang aktif dapat meningkatkan kandungan asam asetat. Asam asetat yang terkandung dalam asap cair sebelum pemurnian adalah $2,63 \%$, sedangkan kandungan asam asetat dalam asap cair setelah pemurnian dengan arang aktif $4,81 \%$. Senyawa fenol yang mempengaruhi warna dan antibakteri mengalami penurunan dari 54,5\% menjadi rata-rata 6,5\% ( Jamilatun, Salamah 2016). Peran fenol sebagai antibakteri masih berfungsi baik dengan adanya asam asetat (Rasydta, 2013).

Pada saat penyimpanan 9-15 jam, mata ikan mulai berubah dari cembung menjadi cekung. Hal ini mengindikasikan bahwa pertumbuhan dan perkembangan mikroogranisme dalam bahan makanan akan menyebabkan perubahan baik yang bersifat fisik maupun kimiawi

Tabel 4. Hasil uji fisik pada sampel ikan Nila yang direndam menggunakan asap cair $10 \%$ dengan variasi waktu simpan

\begin{tabular}{lllll}
\hline Indikator & \multicolumn{3}{c}{ Masa Penyimpanan (Jam) } \\
\cline { 2 - 5 } & $\mathbf{3}$ & $\mathbf{6}$ & $\mathbf{9}$ & $\mathbf{1 2}$ \\
\hline Mata & Jernih dan & Jernih dan & Jernih dan cekung & Jernih dan cekung \\
& Cembung & Cembung & & Cekung \\
Sisik & Menempel & Menempel & Menempel & Menempel \\
Daging & Elastis & Elastis & Elastis & Elastis \\
Insang & Coklat & Putih pucat & Coklat pucat & Coklat muda \\
Bau & Asap cair & Asap cair & Amis dan ada bau & Amis \\
& & & asap cair & Coklat tua \\
Kulit & Kencang & Kencang & Kencang & Kencang \\
Lendir & Tidak ada & Tidak ada & Tidak ada & Tidak ada \\
Warna & Warna khas & Warna khas & Warna khas masih & Warna khas mulai \\
& masih ada & masih ada & ada & Berlendir \\
\end{tabular}


(Jamilatun dan Salamah, 2016).

\section{Kesimpulan}

Dari hasil penelitian ini dapat disimpulkan bahwa, hasil penjernihan asap cair dengan menggunakan arang aktif menyebabkan berkurangnya bau yang sangat menyengat dan menurunkan $\mathrm{pH}$, sedangkan kekeruhan semakin bertambah karena cukup banyak ada sebagian kotoran yang larut dalam asap cair. Konsentrasi optimum asap cair sebagai pengawet adalah $17,5 \%$. Kadar protein pada sampel ikan yang direndam menggunakan asap cair selama masa simpan 15 jam adalah antara 15,54\%-16,63\%. Jumlah total protein yang terkandung dalam sampel ikan Nila dengan perendaman menggunakan asap cair lebih tinggi daripada perendaman menggunakan asap cair tanpa dimurnikan. Jumlah total bakteri dalam sampel ikan Nila yang direndam menggunakan asap cair selama masa simpan 15 jam adalah $57,8 \times 10^{6}-5,8 \times 10^{8} \mathrm{CFU} / \mathrm{g}$.

\section{Ucapan Terima kasih}

Terimakasih kepada DIKTI Departemen Pendidikan Nasional yang telah membiayai penelitian ini dengan Surat perjanjian No: PHB/ 046/ SP3/ III/ 2016.

Terima kasih kepada Putri Rochmatul K. dan Dewi Rusdiarini yang telah membantu dalam penelititan ini.

\section{Daftar Pustaka}

Ariestya, D. I., Swastawati, F. \&Susanto, E., 2016, Antimicrobial activity of microencapsulation liquid smoke on tilapia [Oreochromis niloticus (Linnaeus, 1758)] meat for preservatives in cold storage $\left( \pm 5^{\circ} \mathrm{C}\right)$, Aquatic Procedia, Vol. 7, 19-27.

Atmaja, A. K., 2009, Aplikasi asap cair re-distilasi pada karakterisasi kamaboko ikan Tongkol (Euthynus affinis) ditinjau dari tingkat keawetan dan kesukaan konsumen. Skripsi Fakultas Pertanian, Surakarta: Universitas Sebelas Maret.
Ayudiarti, L. D. \& Sari, N. R., 2010, Asap cair dan aplikasinya pada produk perikanan, Squalen, Vol. 5, 101-108.

Darmadji, P., 2009, Teknologi asap cair dan aplikasinya pada pangan dan hasil pertanian. Teks Pidato Pengukuhan Guru Besar Bidang Bioteknologi Pangan dan Hasil Pertanian Fakultas Teknologi Pertanian, Yogyakarta: Universitas Gadjah Mada.

Jamilatun, S. \& Salamah, S., 2015, Peningkatan kualitas asap cair dengan menggunakan arang aktif, Prosiding Simposium Nasional Teknologi Terapan 3, hlm. 19-24.

Jamilatun, S. \& Salamah, S., 2016, Pengaruh perendaman ikan Nila dengan asap cair (liquid smoke) terhadap daya simpan Prosiding Seminar Nasional Sanis dan Teknologi Universitas Muhammadiyah Jakarta, hlm. 18.

Lingbeck, J. M., Cordero, P., O’Bryan, C. A., Johnson, M. G., Ricke, S. C. \& Crandall, P. G., 2014, Meat Science, Vol. 97, 197-206.

Purwani, E. \& Hapsari S. W. N., 2011, Pengaruh ekstrak jahe (zingiber officinale) terhadap penghambatan mikroba perusak pada ikan Nila (Oreochromis niloticus), Jurnal Kesehatan, Vol. 4 No. 1, Juni: 80-91.

Rasydta, H. P., 2013, Penggunaan asap cair tempurung kelapa dalam pengawetan ikan Bandeng. Skripsi Fakultas Matematika dan Ilmu Pengetahuan Alam, Semarang: Universitas Negeri Semarang.

Saloko, S., Darmadji, P., Bambang, S. \& Yudi, P., 2014, Antioxidative and antimicrobial activities of liquid smoke nanocapsules using chitosan and maltodextrin and its application on Tuna fish preservation, Food Bioscience, Vol. 7, 71-79.

Yunus, M., 2011, Teknologi pembuatan asap cair dari tempurung kelapa sebagai pengawet makanan, Jurnal Sains dan Inovasi, Vol. 7 No. 1, 53-61. 